\title{
Miller Fisher syndrome and cutaneous T-cell lymphoma
}

\begin{tabular}{c} 
Catalina Elena Bistriceanu1, Florentina Anca Danciu1, \\
Dan Iulian Cuciureanu',2 \\
1"Prof. Dr. N. Oblu" Neurosurgery Clinical Emergency Hospital, Iasi, Romania \\
2"Grigore T. Popa" University of Medicine and Pharmacy, Iasi, Romania \\
\hline
\end{tabular}

ABSTRACT
The association between Miller Fisher syndrome (MFS) and non-Hodgkin lymphoma is re-ported in a few cases in
the current literature. We report a case of a patient known with Mycosis fungoides - cutaneous T cell lymphoma
(CTCL) that developed, after 6 years of illness, a variant of Guillain Barré syndrome - Miller Fisher syndrome. The
diagnosis was established based on clinical features and positive antiganglioside antibodies (anti GQ1b and anti
GT1a antibodies). The neurological involvement in cutaneous T cell lymphoma has been seldom reported and the
mechanism is not completely elucidated.

Keywords: Miller Fisher syndrome (MFS), cutaneous T cell lymphoma (CTCL), Mycosis fungoides, anti-ganglioside antibodies

\section{INTRODUCTION}

Mycosis fungoides is a non-Hodgkin's, peripheral T-cell lymphoma of the skin with a wide spectrum of potential clinical manifestations (1). Some histological findings are important and a lymphocytic infiltrate in the superficial dermis might be observed, with lymphocytes migrating among epidermal keratinocytes (epidermotropism) (1-3). Miller Fisher syndrome is a variant of Guillain-Barré syndrome characterized by ataxia, areflexia and ophtalmoplegia; the anti-GQ1b antibodies allows a greater diagnostic certainty (4).

Four cases of lymphoma-associated "atypical" Miller Fisher syndrome were retrieved from the literature (5). The autoimmunity due to oncoantigen may induce misdirected immune targets against epitopes presented in the peripheral nervous system $(6,7)$. This mechanism may be involved in the case described above with cutaneous T-cell lymphoma (Mycosis fungoides) and Miller Fisher syndrome.

\section{CASE REPORT}

A 68 year old patient came in the emergency department for intermittent double vision, liquids swallowing problems, dysphonia, weakness and paraesthesias in hand and feet, started one week prior to the presentation.

His past medical history included cutaneouns T-cell lymphoma - stage IA Mycosis fungoides diagnosed in 2012 based on the following criteria:

1. a 10 year history of multiple pruriginous erythemaous plaques on calves and right arm;

2. a cutaneous biopsy (January 2012) revealed epidermic hyperplasia with long dermic papillae; superficial derm lymphoid infiltrate, especially on basal layer, without Pautrier microabscess (pagetoid reticulosis); the lymphoid infiltrate is based on small lymphocites associated with isolated big cells with irregular nuclear outline;

3 . the immunohistochemistry (ICH): positive CD3, CD5, CD4 - diffuse in the major part of the lymphoid population; positive CD20 in rare lymphocytes; positive CD8 in rare lymphocytes with a CD4/CD8 report in the favor of CD4; positive $\mathrm{CD} 30, \mathrm{~K} 167$ in rare big cells;

The toraco-abdominal CT scan and medullary punction excluded lymphadenopathies, visceral or medullary involvement.

The patient was diagnosed with IA cutaneous T-cell non-Hodgkin lymphoma / Mycosis fungoides 
(table 1, table 2) and he was treated with topical treatment. In 2013 the histopathological and the immunochemistry reexaminations were performed so that a more accurate diagnosis will be made. The cutaneous fragment had a lymphoid proliferation in superficial dermis, with small, medium size and irregular nuclei; the overlying epidermis had sharp epidermal crests, spongiosis and exocytosis with polymorphonuclear leucocytes and vesicles in superficial layers. The immunohistochemistry results were: CD3, CD5, CD4-positive in tumoral lymphoid population, CD20-negative in lymphoid population, positive in reactive $\mathrm{B}$ cells, CD8-difficult to interpret, $\mathrm{Ki} 67<10 \%$. Based on clinical, pathologic and molecular feature, the diagnosis of mycosis fungoides was given.

TABLE 1. Original Mycosis fungoides Cooperative Group TNM classification of cutaneous T-cell lymphoma (CTCL) (8)

\begin{tabular}{|l|l|}
\hline Classification & Description \\
\hline T: Skin & $\begin{array}{l}\text { T0 Clinically and/or histopathologically suspi- } \\
\text { cious lesions }\end{array}$ \\
\hline & $\begin{array}{l}\text { T1 Limited plaques, papules, or eczematous } \\
\text { patches covering 10\% of the skin surface }\end{array}$ \\
\hline & $\begin{array}{l}\text { T2 Generalized plaques, papules, or erythema- } \\
\text { tous patches covering 10\% or more of the skin } \\
\text { surface }\end{array}$ \\
\hline & T3 Tumors, one or more \\
\hline & T4 Generalized erythroderma \\
\hline
\end{tabular}

\begin{tabular}{|c|c|}
\hline Classification & Description \\
\hline \multirow[t]{4}{*}{$\begin{array}{l}\text { N: Lymph } \\
\text { nodes }\end{array}$} & $\begin{array}{l}\text { NO No clinically abnormal peripheral lymph } \\
\text { nodes; pathology nega ve for CTCL }\end{array}$ \\
\hline & $\begin{array}{l}\text { N1 Clinically abnormal peripheral lymph nodes; } \\
\text { pathology nega ve for CTCL }\end{array}$ \\
\hline & $\begin{array}{l}\text { N2 No clinically abnormal peripheral lymph } \\
\text { nodes; pathology posi ve for CTCL }\end{array}$ \\
\hline & $\begin{array}{l}\text { N3 Clinically abnormal peripheral lymph nodes; } \\
\text { pathology posi ve for CTCL }\end{array}$ \\
\hline \multirow{2}{*}{$\begin{array}{l}\text { B: Peripheral } \\
\text { blood }\end{array}$} & B0 Atypical circula ng cells not present ( $5 \%$ ) \\
\hline & $\begin{array}{l}\text { B1 Atypical circula ng cells present ( } 5 \%) \text {; re- } \\
\text { cord total white blood count and total lympho- } \\
\text { cyte counts, and number of atypical cells/100 } \\
\text { lymphocytes }\end{array}$ \\
\hline \multirow{2}{*}{$\begin{array}{l}\text { M: Visceral } \\
\text { organs }\end{array}$} & MO No visceral organ involvement \\
\hline & $\begin{array}{l}\text { M1 Visceral involvement (must have pathol- } \\
\text { ogy confirma on and organ involved should be } \\
\text { specified) }\end{array}$ \\
\hline
\end{tabular}

He was addmited in the Neurology department on may 2018 for the symptoms previously described. On admission in our clinic, his vital signs were normal.

The clinical examination revealed pruriginous hyperpigmented patches and plaques, petechiae on anterior and posterior trunk, tights and calves, right axillary erythematous area, erytemato-scuamous area with keratin crusts on anterior left thigh and right calf (Figure 1).
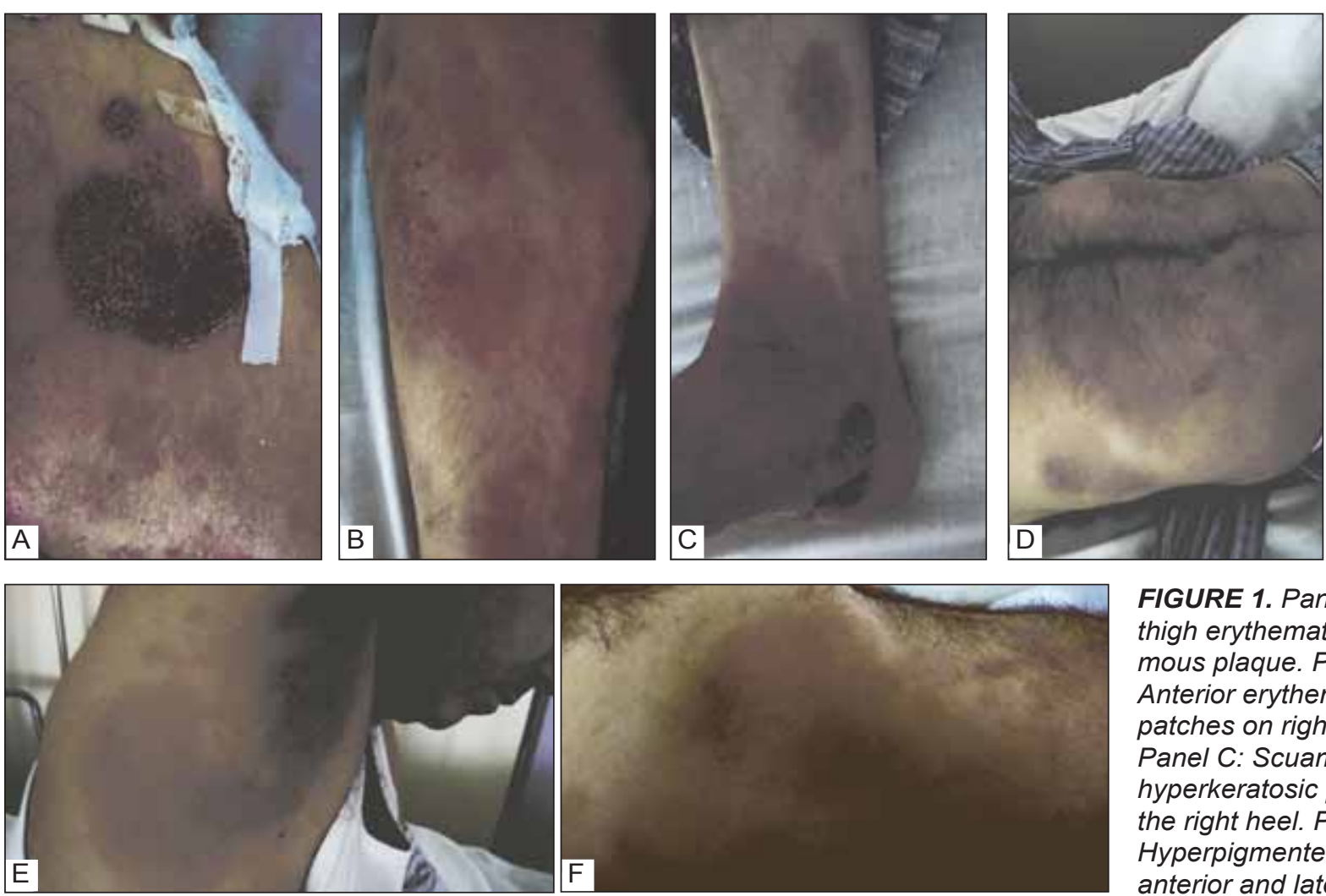

FIGURE 1. Panel A: Left thigh erythemato-scuamous plaque. Panel B: Anterior erythematos patches on right calf. Panel C: Scuamous hyperkeratosic plaque on the right heel. Panel D-E: Hyperpigmented areas on anterior and lateral trunk. 
TABLE 2. The staging system designed by the Committee on Staging and Classification of cutaneous T-cell lymphomas and published by Bunn and Lamberg in 1979 (9)

\begin{tabular}{|c|l|}
\hline IA & T1NOM0 \\
\hline IB & T2NOM0 \\
\hline IIA & T1-2N1M0 \\
\hline IIB & T3N0-1M0 \\
\hline IIIA & T4NOM0 \\
\hline IIIB & T4N1M0 \\
\hline IVA & T1-4N2-3M0 \\
\hline IVB & T1-4N0-3M1 \\
\hline
\end{tabular}

No lymphadenopathy or organomegaly could be detected.

The neurologic examination revealed normal cognitive function; the cranial nerve examination revealed bilateral ophtalmoplegia (grade I-II left ptosis, normal pupillary reactions, limited lateral gaze in left eye on abduction, intermittent horizontal diplopia), bulbar nerve palsies (dysphonia and dysphagia for liquids and solids, diminished superior gag reflexes and weakness when the patient opened his mouth to show the palate elevation); coordination was impaired in upper and lower limbs: he had dysmetria bilaterally (more obvious on right) on finger-to-nose testing and heel-to-shin testing; the plantar responses were left Babinski sign and right flexion; Muscle stretch reflexes revealed decreased reflexes in lower limbs; Sensory examination revealed decreased sensation of pinprick, light touch and vibration in distal feet.

TABLE 3. Laboratory data

\begin{tabular}{|l|c|c|}
\hline Variable & Value & $\begin{array}{c}\text { Reference Range } \\
\text { Adults }\end{array}$ \\
\hline WBC count & $7.3^{*} 10^{3} / \mathrm{mmc}$ & $4-9 * 10^{3} / \mathrm{mmc}$ \\
\hline RBC count & $4.42 * 10^{3} / \mathrm{mmc}$ & $4-4.5 * 10^{3} / \mathrm{mmc}$ \\
\hline Platelet count & $290^{3} 10^{3} / \mathrm{mmc}$ & $150-400 * 10^{3} / \mathrm{mmc}$ \\
\hline $\begin{array}{l}\text { Mean corpuscular } \\
\text { volume }\end{array}$ & $95 \mathrm{fL}$ & $80-100 \mathrm{fL}$ \\
\hline Hemoglobin & $13.5 \mathrm{~g} / \mathrm{dl}$ & $12-16 \mathrm{~g} / \mathrm{dl}$ \\
\hline CHEM & $32.4 \mathrm{~g} / \mathrm{dl}$ & $32-36 \mathrm{~g} / \mathrm{dl}$ \\
\hline ESR & $10 \mathrm{~mm} / 1 \mathrm{~h}$ & $<20 \mathrm{~mm} / \mathrm{h}$ \\
\hline Crea nin & $0.78 \mathrm{mg} / \mathrm{dl}$ & $0.5-1.2 \mathrm{mg} / \mathrm{dl}$ \\
\hline Alkalin phosphatase & $45 \mathrm{U} / \mathrm{l}$ & $42-98 \mathrm{U} / \mathrm{l}$ \\
\hline AST & $16 \mathrm{U} / \mathrm{l}$ & $0-31 \mathrm{U} / \mathrm{l}$ \\
\hline ALP & $31 \mathrm{U} / \mathrm{l}$ & $0-34 \mathrm{U} / \mathrm{l}$ \\
\hline $\begin{array}{l}\text { Gamma Glutamyl } \\
\text { Transferase }\end{array}$ & $10 \mathrm{U} / \mathrm{l}$ & $0-38 \mathrm{U} / \mathrm{l}$ \\
\hline Lac c dehidrogenase & $344 \mathrm{U} / \mathrm{l}$ & $120-246 \mathrm{U} / \mathrm{l}$ \\
\hline Total Bilirubin & $2.13 \mathrm{mg} / \mathrm{dl}$ & $0.05-1.2 \mathrm{mg} / \mathrm{dl}$ \\
\hline Fibrinogen & $319 \mathrm{mg} / \mathrm{dl}$ & $180-350 \mathrm{mg} / \mathrm{dl}$ \\
\hline
\end{tabular}

\section{INVESTIGATIONS AND DIFFERENTIAL DIAGNOSIS}

The laboratory data revealed a normal cell blood count, increased lactic dehydrogenase and increased total bilirubin (Table 3).

The cerebral MRI excluded secondary lesions associated with Non-Hodgkin Lymphoma like meningeal infiltration of malignant cells (these are rarely cited in the literature). To exclude a paraneoplastic syndrome there were performed anti-neuronal antibodies (Amphiphysin, CV2, PNMA2, Ri, Yo, Hu, Recoverin, SOX1, Titin) - with a negative result.

A lumbar puncture was proposed, but the patient refused it.

We suspected a Lambert-Eaton syndrome evolving in the non-Hodgkin lymphoma. The electrodiagnostic tests confirmed an axonal sensitive polineuropathy. The anti-calcium channel antibodies type $\mathrm{N}$ and $\mathrm{PQ}$ were negative.

Another hypothesis was CANOMAD syndrome (Chronic Ataxic Neuropathy Ophtalmoplegia M-protein Agglutination Disialosyl antibodies syndrome). The seric protein electrophoresis revealed the absence of monoclonal IgG/ IgA/ IgM/ kappa, lambda chains; the direct Coombs test was negative.

The anti-gangloside (Ig G/Ig M) antibodies were positive for anti-GQ1B and anti-GT1A (Table 4). These autoantibodies are associated with Miller Fisher syndrome - sensitivity $>90 \%$, specificity $>$ $90 \%$.

The patient had an excellent response to corticosteroids. He was directed to oncology for reexamination and disease staging.

TABLE 4. The anti-ganglioside antibodies

\begin{tabular}{|l|c|}
\hline An -ganglioside an bodies (Ig G/ Ig M) & \\
\hline An -GM1, An -GM2, An -GM3, An -GM4 & Nega ve \\
\hline An -GD1a & Nega ve \\
\hline An -GD1b & Nega ve \\
\hline An -GD2, An -GD3 & Nega ve \\
\hline An - GT1a & Posi ve \\
\hline An - GT1b & Nega ve \\
\hline An -GQ1b & Posi ve \\
\hline
\end{tabular}

\section{DISCUSSIONS}

There are 4 cases in the literature with the association between Miller Fisher syndrome and lym- 
phoma: 1 - Mixed cellularity Hodgkin lymphoma (10), 2 - Burkitt's lymphoma (11), 3 - B-cell chronic lymphocytic leukemia (12), 4 - diffuse large B-cell lymphoma (13). The temporal correlations were: in the first case the MFS appearance was in the second relapse of the lymphoma (10); in the second case the MFS was in the same time with the discovery of the lymphoma in a renal transplant recipient on anti-rejection therapy (11); in the third case the onset of MFS was during chemotherapy in a chronic lymphocitic leukemia (12); in the fourth case the evaluation of a recurrent MFS detected lymphoma (13). The first case was associated with an elevated serum anti-GQ1b antibody titre (useful supportive evidence for MFS) and 3 patients showed only elevated protein concentrations. The electrodiagnostic tests were interpreted as: axonal sensory polyneuropathy (10); axonal sensorimotor polyneuropathy $(11,12)$, sensorimotor demyelinating polyradiculoneuropathy (13). The responses to treatment were different: 1st, 3rd, 4th patient responded to immunomodulating therapy; the 2nd patient was unresponsive to immunomodulating therapy but had an improvement to systemic therapy for lymphoma. The 4th patient showed neurological improvement to a combined systemic/intrathecal chemotherapy regimen (13). This fact was interpreted as evidence of a "paraneoplastic" pathogenesis (the production of a specific antibody against an antigen of malignant cells that cross-reacts with an antigen of normal neurological tissue) (5).

The malignant cells in Mycosis fungoides are able to reside in the skin through complicated immune mechanisms. These cells express E-selectin and migrate along endothelial cells. Chemokine receptors from $\mathrm{T}$ cells (chemokine receptor 4) recognize chemokines from epidermis (chemokine ligand 17) and bound to the luminal side of endothelial cells. The next step is the extravasation into dermis; the lymphoma cells are clustering around Langerhans cells, forming Pautrier's microabcesses (1).

The autoimmune mechanisms in non-Hodgkin lymphoma could be represented by oncoantigens inducing misdirected immune targets against epitopes from peripheral nervous system (14). The axonal neuropathy may be also secondary to an epineurinal and endoneurial infiltration by malignant cells.

Due to the fact that patients had a neurological improvement after systemic chemotherapy, we reinforce the idea that specific antibodies against antigens of the malignant cells cross-react with parts of neuronal components (13).

In our case, we noticed a significant improvement of the neurologic symptoms after corticosteroids. This recovery of these symptoms after the therapy suggests an immune-mediated mechanism of the disease that may be assumed with a breakdown of the blood-nerve barrier and immune mediated inflammation (15).

\section{CONCLUSIONS}

Patients with non-Hodgkin's lymphoma may develop inflammatory, autoimmune conditions such as brachial plexopathy, Guillain-Barré syndrome, CIDP (16) or Miller Fisher syndrome, like in our case. There are many theories about the pathogenesis of the peripheral nervous system and lymphoma: invasion of tumoral cells, metabolic processes, vascular impairment, immunologic mechanisms including paraneoplastic neuropathy $(17,18)$.

In our case, the neurologic complication occurred in the remission of the lymphoma and we detailed above a probable immune mediated mechanism. In this case, the improvement after corticosteroids sustains the immunologic involvement.

Future perspectives are directed to the identification of the cellular mechanisms and the use of molecular antagonists in therapies.

Conflict of interest: none declared Financial support: none declared

\section{REFERENCES}

1. Girardi, Michael et al. The Pathogenesis of Mycosis fungoides. New England Journal of Medicine 2004;350:1978-8.

2. Glusac EJ, Shapiro PE, McNiff JM. Cutaneous T-cell lymphoma: Refinement in the application of controversial histologic criteria. Dermatol Clin 1999;17:601-14.
3. Liu V, McKee PH. Cutaneous T-cell lymphoproliferative disorders: Approach for the surgical pathologist: Recent advances and clarification of confused issues. Adv Anat Pathol 2002;9:79-100.

4. Yepishin IV, Allison RZ, Kaminskas DA, Zagorski NM, Liow KK. Miller Fisher Syndrome: A Case Report Highlighting Heterogeneity of 
Clinical Features and Focused Differential Diagnosis. Hawaii Journal of Medicine \& Public Health. 2016;75(7):196-199.

5. Stübgen, Joerg-Patrick. Lymphoma-associated dysimmune polyneuropathies. Journal of the Neurological Sciences, Volume 355, Issue 1, 25 - 36

6. F. Seffo and HA Daw. Non-hodgkin lymphoma and Guillain-Barré syndrome: A rare association. Clinical Advances in Hematology and Oncology, vol. 8, no. 3, pp. 201-203, 2010.

7. P. Giglio and M.R. Gilbert. Neurologic complications of non-Hodgkin's lymphoma. Current Hematologic Malignancy Reports, vol. 1, no. 4, pp. 214-219, 2006.

8. Olsen, Elise A et al. Revisions to the staging and classification of mycosis fungoides and Sezary syndrome: a proposal of the International Society for Cutaneous Lymphomas (ISCL) and the cutaneous lymphoma task force of the European Organization of Research and Treatment of Cancer (EORTC). Blood 1106 (2007): 1713-22.

9. Bunn PA Jr, Lamberg SI. Report of the Committee on Staging and Classification of Cutaneous T-Cell Lymphomas. Cancer Treat Rep 1979;63:725-8.

10. E. Rubio-Nazabal, J. Marey-Lopez, J.P. Torres-Carrete, P. AlvarezPerez, P. Rey Del Corral. Miller-Fisher syndrome and Hodgkin's disease. J. Neurol. Neurosurg. Psychiatry 73 (2002) 344.
11. S. Gentile, M. Messina, I. Rainero, R. Lo Guidice, P. De Martino, L. Pinessi. Miller Fisher syndrome associated with Burkitt's lymphoma. Eur. J. Neurol. 13 (2006) 430.

12. Z. Aki, O. Aksoy, G. Sucak, R. Kuruoglu, M. Yagci. Miler-Fisher syndrome associated with chronic lymphocytic leukemia. Neurol. India 56 (2008) 196-200.

13. N. Usmani, R. Bhatia, O.F. Ikpatt, K.R. Sharma, Diffuse large B-cell lymphoma presenting as Miller Fisher syndrome. Muscle Nerve 45 (2012) 138-143.

14. R.H. Bishay, J. Paton, and V. Abraham, Variant Guillain-Barré Syndrome in a Patient with Non-Hodgkin's Lymphoma. Case Reports in Hematology, vol. 2015.

15. M. Wada, K. Kurita, K. Tajima, T. Kawanami, and T. Kato. A case of inflammatory demyelinating polyradiculoneuropathy associated with T-cell lymphoma. Acta Neurologica Scandinavica, vol. 107, no. 1, pp. 62-66, 2003.

16. Kelly, JJ and Karcher, DS. Lymphoma and peripheral neuropathy: A clinical review. Muscle Nerve, 31(2005): 301-313.

17. Hughes RA, Britton T, Richards M. Effects of lymphoma on the peripheral nervous system. J R Soc Med 1994;87:526-530.

18. Vallat J, De Mascarel H, Bordessoule D, Jauberteau M, Tabaraud F, Gelot A et al. Non-Hodgkin malignant lymphomas and peripheral neuropathies - 13 cases. Brain 1995;118:1233-1245. 